\title{
Patterns of Spatial Overlap between Non-Indigenous and Critically Endangered Freshwater Fishes from a Mediterranean Biodiversity Hotspot ${ }^{+}$
}

\author{
Nicholas Koutsikos ${ }^{1,2, *}$, Leonidas Vardakas ${ }^{1,3}$, Olga-Ioanna Kalantzi ${ }^{2}$ and Stamatis Zogaris 1 (D) \\ 1 Hellenic Centre for Marine Research, Institute of Marine Biological Resources and Inland Waters, Anavissos, \\ 19013 Attica, Greece; lvard@hcmr.gr (L.V.); zogaris@hcmr.gr (S.Z.) \\ 2 Department of Environment, University of the Aegean, 81100 Mytilene, Greece; kalantzi@aegean.gr \\ 3 Department of Forestry and Management of the Environment and Natural Resources, \\ Democritus University of Thrace, 193 Pantazidou St., 68200 Orestiada, Greece \\ * Correspondence: nkoutsik@hcmr.gr; Tel.: +30-22910-76393 \\ + Parts of this article have been presented at the 1st International Electronic Conference on Biological Diversity, \\ Ecology and Evolution, 15-31 March 2021, as "Overlapping Areas of Non-Indigenous and Critically Endangered \\ Freshwater Fishes: Setting Conservation Priorities in Greece". Available online: https://bdee2021.sciforum.net/.
}

Citation: Koutsikos, N.; Vardakas, L. Kalantzi, O.-I.; Zogaris, S. Patterns of Spatial Overlap between

Non-Indigenous and Critically Endangered Freshwater Fishes from a Mediterranean Biodiversity Hotspot ${ }^{\dagger}$. Diversity 2021, 13, 233. https:/ / doi.org/10.3390/d13060233

Academic Editor: Michael Wink

Received: 21 April 2021

Accepted: 23 May 2021

Published: 26 May 2021

Publisher's Note: MDPI stays neutral with regard to jurisdictional claims in published maps and institutional affiliations.

Copyright: (c) 2021 by the authors. Licensee MDPI, Basel, Switzerland. This article is an open access article distributed under the terms and conditions of the Creative Commons Attribution (CC BY) license (https:// creativecommons.org/licenses/by/ $4.0 /)$.

\begin{abstract}
Non-indigenous fish species (NIFS) can cause severe ecological impacts on the invaded ecosystems and are considered as one of the leading factors of freshwater biodiversity loss. Unraveling the spatial overlap between NIFS and critically endangered (CR) fish species can contribute to targeted conservation actions to minimize the potential negative effects. In this study, we applied geostatistical analyses to investigate the spatial overlap of NIFS against fish species that are designated under the CR status according to the IUCN and the Hellenic Zoological Society (HZS) Red Lists. Distributional data (presence-absence) from 800 records of 52 NIFS were compiled for both lentic and lotic ecosystems of Greece. Our results indicate that freshwater ecosystems under high NIFS richness were located mainly in lowland areas and often near large cities and ecosystems with well-developed commercial and recreational fisheries. On the contrary, low NIFS richness was observed in mountainous regions and in relatively small river basins. Overlapping areas of CR species with moderate to high NIFS richness (1.5-4.3 NIFS per $\left.1 \mathrm{~km}^{2}\right)$ were relatively high $(\sim 50 \%)$. A quarter of the overlapping areas (24.8\%) fall within NATURA 2000 network, where legal management bodies could implement specialized programs to minimize the negative impacts. However, the majority of CR fish species' distribution remains in unprotected areas indicating that protected areas should be re-designed to include areas containing freshwater species under the highest threatened category. Our findings demonstrate that whole assemblages of fishes are rapidly changing as NIFS spread into Greece and many freshwater ecosystems of outstanding biodiversity conservation value are under significant invasion pressure.
\end{abstract}

Keywords: invasive species; alien; translocated; critically endangered; freshwater fishes; freshwater ecosystems; conservation; biodiversity; red list

\section{Introduction}

Recent scientific studies have indicated that biodiversity is declining at an extremely rapid rate, suggesting that the sixth mass extinction of species is already under way [1-3]. Indeed, according to the International Union for the Conservation of Nature (IUCN), more than 35,500 species (or $28 \%$ of all assessed species) are threatened with extinction worldwide, while at least 1677 species out of 15,060 assessed are threatened with extinction in Europe. Freshwater fishes are considered among the most threatened species worldwide [4,5]. The most recent IUCN Red List includes 20,109 species belonging to the class of Actinopterygii, 51.8\% of which inhabit freshwater ecosystems (10,434 species), where 2234 species (i.e., $22 \%$ ) of the 
freshwater species are at risk of global extinction as they are under a threatened category (CR: Critically Endangered (576 species; 5.5\%), EN: Endangered (857 species; 8.2\%), VU: Vulnerable (961 species; 9.2\%)). In Europe, freshwater fishes display the third highest percentage of taxa which are at risk; that is, in order of extinction risk: freshwater mollusks $(59 \%)$, endemic trees $(58 \%)$, and freshwater fish ( $40 \%)$. Pollution is one of the major threats that significantly affects freshwater fish species in the European region [6]; however, currently it is not considered the leading factor for species extinctions. Other pressures such as over-abstraction, combined with the increasing frequency of drought events due to climate change [7], the disruption of river connectivity due to the construction of multiple barriers [8], and the introduction of invasive alien species severely affect the viability of the native freshwater fish fauna of Europe [9].

Freshwater fish species inhabiting Mediterranean inland water ecosystems are considerably more vulnerable compared to the species located in the northern temperate regions of Europe since they are forced to survive under diverse and unstable hydrological regimes [10]. In addition, a large number of the fish species occurring in Mediterranean countries display a range-restricted geographical distribution, as they may occur in a single river or lake [11], thus making them even more vulnerable to additive threats. Greece, located in the eastern Mediterranean region, holds a unique ichthyofaunal diversity within Europe and displays one of the highest levels of fish species endemism in the Mediterranean $[10,12]$. The complex geological processes of the wider area of the Balkans and the eastern Mediterranean has allowed multiple fish species colonizations, long-term survival of ancient taxa in aquatic refugia, and enhanced speciation due to long-term biogeographical barriers that enhance hydrographic isolation among very different biogeographic areas $[12,13]$. These factors are mainly responsible for the increased diversity and high degree of endemicity in Greece's freshwater fish fauna.

As elsewhere in the Mediterranean basin, anthropogenic alterations such as habitat degradation and fragmentation are the main threats for freshwater fishes in Greece [13]. These anthropogenic stresses are also augmented by the introduction of alien and intracountry translocated fishes (i.e., species transferred out of their natural distributional range but within the country limits) [14]. Non-indigenous species can have severe ecological impacts on the recipient ecosystems they invade. Due to the possible absence of natural predators they are able to increase in numbers and disperse to new areas. In addition, they can hybridize with related native species, spread diseases, compete and displace native species, and alter the structure and function of ecosystems, even leading to local extinctions of native species $[15,16]$.

The aim of this study was to identify the potential overlapping areas of non-indigenous fish species (hereafter NIFS) against fish species that are designated under critically endangeredCR status according to the IUCN and the Hellenic Zoological Society (HZS) Red Lists. This applied geographical analysis aims to support conservation planning and actions to minimize the potential negative effects that NIFS may pose to freshwater biodiversity.

\section{Materials and Methods}

\subsection{Study Area and Species Pool}

According to the most recent checklist to date [17], 160 fish species have been recorded in freshwater ecosystems of Greece, where 137 are native. The country presents a substantial proportion of country-specific endemics, 47 in total (or $34 \%$ of the native fish fauna). Moreover, a further $10 \%$ of the freshwater fish species are "near endemic"; that is, occurring also in shared transboundary freshwater lake basins. By excluding aliens and species of marine origin, the percentage of endemic and near-endemic species rises to $57 \%$. In Greece, 51 fish species are considered threatened at a global scale (i.e., CR, Critically Endangered (20); EN, Endangered (15); and VU, Vulnerable (16)) corresponding to $31.8 \%$ of all native inland water fish species in Greece based on the most recent IUCN Red List and distinctions made in Barbieri et al. [17]. 


\subsection{Data Acquisition}

We obtained geographic range data for fish species designated as critically endangered (CR) based on the IUCN Red List integrated with the critically endangered fish species listed by the Hellenic Zoological Society (HZS) Red List (Table 1). The distributional range of CR species have been developed during the conservation status assessment of EU species of conservation concern [18]. Furthermore, we included three additional fish species not yet evaluated since they display extremely restricted distributional ranges in Greece.

Table 1. Freshwater fish species of Greece listed as Critically Endangered (CR) under IUCN and/or the HZS Red Lists. Categories: CR, Critically Endangered; EN, Endangered; VU, Vulnerable; LC, Least Concern; and DD, Data Deficient. Transl. in brackets denotes species that are introduced as translocated populations, not the original wild stock. Species with an asterisk are currently presumed extirpated or extinct in Greece.

\begin{tabular}{|c|c|c|c|}
\hline Species & Authority & IUCN Red List & HZS Red List \\
\hline Acipenser naccarii * & Bonaparte, 1836 & CR & [Transl.] \\
\hline Acipenser stellatus * & Pallas, 1771 & $\mathrm{CR}$ & $\mathrm{DD}$ \\
\hline Acipenser sturio * & Linnaeus, 1758 & CR & DD \\
\hline Alburnus macedonicus & Karaman, 1928 & CR & CR \\
\hline Alburnus vistonicus & Freyhof and Kottelat, 2007 & CR & CR \\
\hline Alosa vistonica * & Economidis and Sinis, 1986 & CR & CR \\
\hline Aphanius almiriensis & Kottelat, Barbieri, and Stoumboudi, 2007 & CR & CR \\
\hline Barbus euboicus & Stephanidis, 1950 & CR & CR \\
\hline Barbus pergamonensis & Karaman, 1971 & $\mathrm{LC}$ & CR \\
\hline Caspiomyzon graecus & Renaud and Economidis, 2010 & - & - \\
\hline Caspiomyzon hellenicus & Vladykov, Renaud, Kott, and Economidis, 1982 & CR & CR \\
\hline Cobitis stephanidisi & Economidis, 1992 & CR & CR \\
\hline Eudontomyzon sp. Almopaios & Provisionally in Barbieri et al. 2015 & - & - \\
\hline Huso huso * & (Linnaeus, 1758) & CR & [Transl.] \\
\hline Knipowitschia goerneri & Ahnelt, 1991 & DD & CR \\
\hline Knipowitschia milleri & (Ahnelt and Bianco, 1990) & CR & VU \\
\hline Oxynoemacheilus theophilii & Stoumboudi, Kottelat, and Barbieri, 2006 & $\mathrm{LC}$ & CR \\
\hline Pelasgus epiroticus & (Steindachner, 1896) & CR & CR \\
\hline Pelasgus laconicus & (Kottelat and Barbieri, 2004) & CR & CR \\
\hline Pungitius hellenicus & Stephanidis, 1971 & CR & CR \\
\hline Salaria economidisi & Kottelat, 2004 & CR & LC \\
\hline Scardinius graecus & Stephanidis, 1937 & CR & VU \\
\hline Squalius sp. Evia & Provisionally in Kottelat and Freyhof 2007 & $\mathrm{CR}$ & - \\
\hline Valencia letourneuxi & (Sauvage, 1880$)$ & CR & CR \\
\hline Valencia robertae & Freyhof, Kärst, and Geiger, 2014 & - & - \\
\hline
\end{tabular}

In total, 25 freshwater fish species were included in our dataset: 19 by IUCN, three species under the HZS Red List (Barbus pergamonensis, Knipowitschia goerneri, Oxynoemacheilus theophilii), and three additional species which are not yet formally evaluated (Caspiomyzon graecus, Eudontomyzon sp. Almopaios, Valencia robertae), displaying however restricted distributional ranges (Table 1). The European eel, Anguilla anguilla (L.), a widespread euryhaline fish of marine origin, was excluded from our dataset due to its broad distributional range in the country, considering that this species could confound our analyses.

The geographical distribution of NIFS in Greece was compiled based on data from two different sources: a) a bibliographical survey for lentic ecosystems and b) survey data from standardized field surveys in lotic ecosystems (rivers, streams, canals, and springs) in the framework of various national and local projects. The derived matrix summarized records from 169 lakes, 154 with at least one NIFS and 15 with none, within the Greek territory (Figure 1). Data of fish species in lentic waters-lakes, reservoirs and ponds-were obtained from both field surveys and bibliographical data between the years 2001 and 2020 (107 artificial and 62 natural). Fish sampling data in lotic waters were acquired from research surveys conducted between the years 2001-2017 by the Hellenic Centre for Marine Research (HCMR); these cover the entire mainland as well as the major islands of Greece. 
Most of the sampled data have been recently published [14,19]. Field samplings were conducted primarily through a standardized electrofishing procedure following the FAME research project guidelines [20] with some modifications; for a detailed description of the sampling procedure see [21]; in some cases seine nets and other methods were also used to ascertain fish presence. In total, 265 lotic sites with at least one NIFS and 366 sites without NIFS in Greece were compiled (Figure 1). Barbieri et al. [17] was used for species taxonomy and nomenclature. Species that are introduced by humans beyond their native freshwater ecoregion, but are native to a part of the country, are designated as translocated species [22]. NIFS include both alien and translocated species in all analyses.

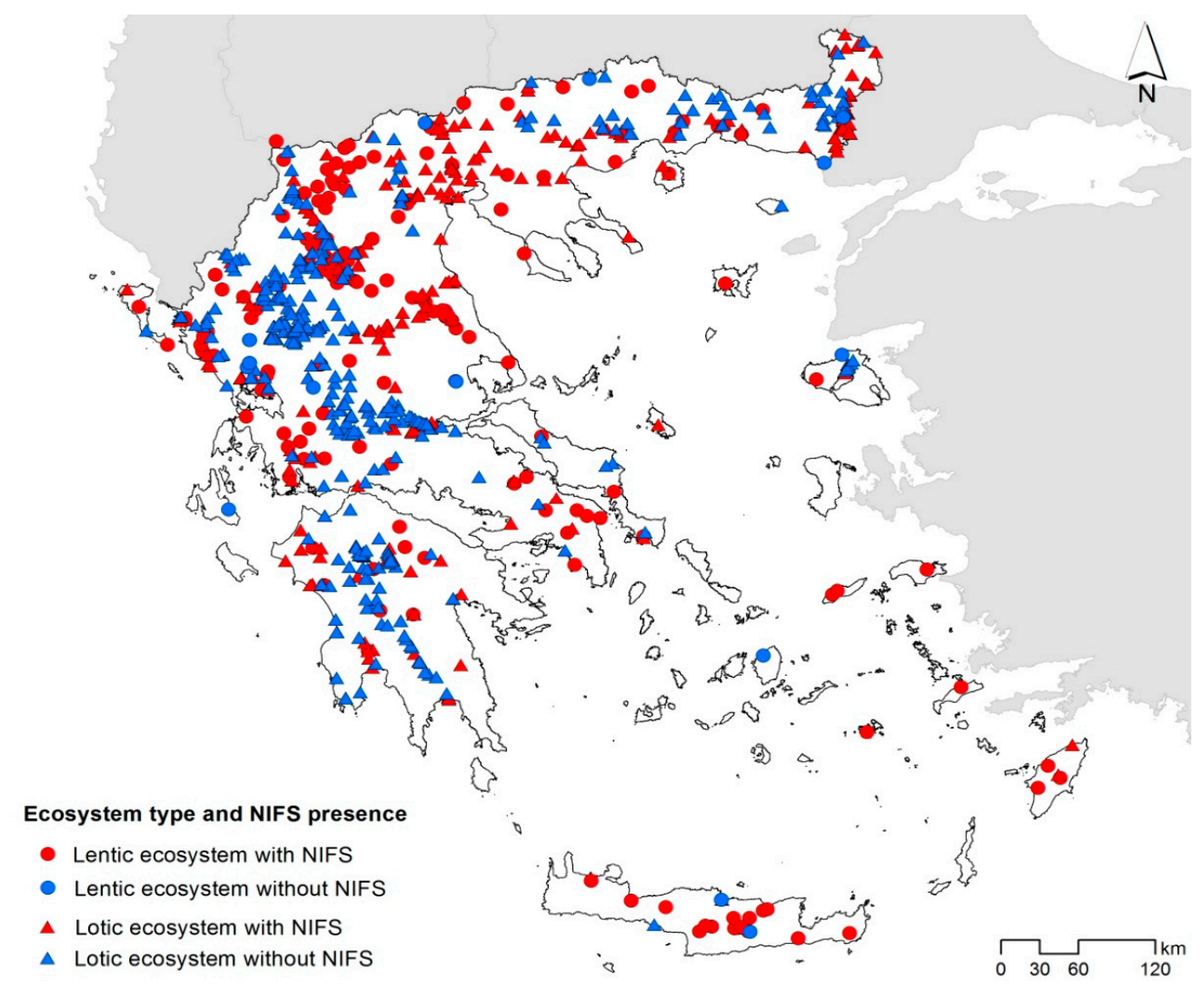

Figure 1. Map of Greece indicating the location of lentic (points) and lotic (triangles) ecosystems used in this study. Red symbols indicate locations occupied with NIFS and blue NIFS-free locations.

\subsection{Spatial Analysis}

Spatial analyses of species distributional data were performed in order to investigate the potential overlapping areas of NIFS against fish species that are designated under a $\mathrm{CR}$ status. The geographical range of each CR fish species was projected within grid cells of $1 \times 1 \mathrm{~km}$ in a geographical information system (ESRI-ArcGIS v. 10.4; Figure 2), and the final matrix generated by the total number of CR species in each cell. The predictive distributional patterns of NIFS richness was generated by using presence/absence NIFS data through the Kriging interpolation analysis in ArcGIS, initially separately for lotic and lentic ecosystems to identify possible differences or limitations attributed to the ecosystems investigated. The overlapping "conflict areas" were spatially delimited by the produced NIFS distributional patterns within the geographical range of CR fish species. Finally, we compared the distribution of $\mathrm{CR}$ fish species richness of the overlapping areas for protected areas (i.e., Greece's Natura 2000 network) versus areas outside protected regions. 


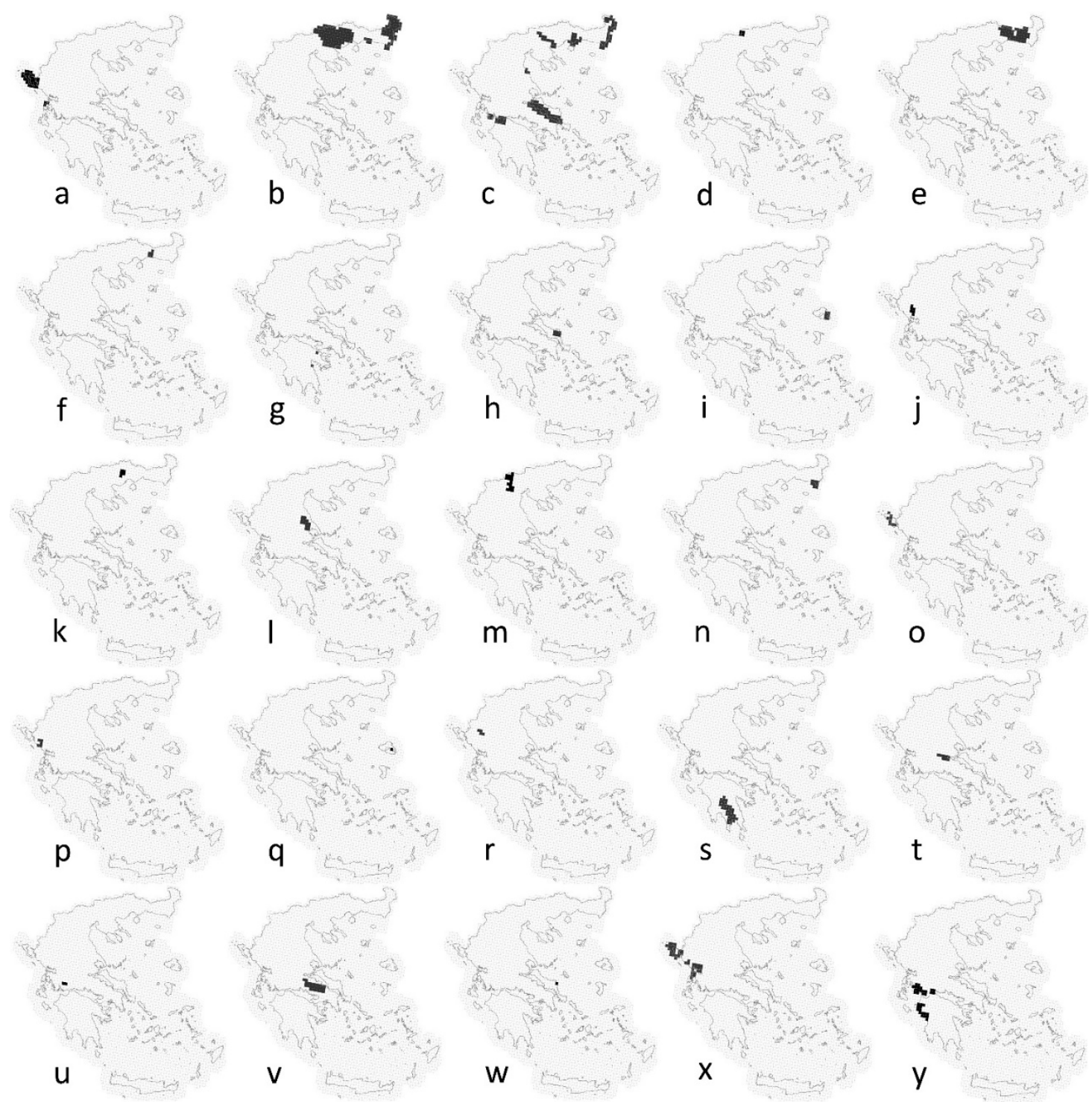

Figure 2. Geographical ranges of $\mathrm{CR}$ fish species in Greece projected in $1 \times 1 \mathrm{~km}$ grid cells. Background colored areas show terrestrial (green) and marine (blue) EU Natura 2000 protected areas. Codes: (a) A. naccarii; (b) A. stellatus; (c) A. sturio; (d) A. macedonicus; (e) A. vistonicus; (f) A.vistonica; (g) A.almiriensis; (h) B. euboicus; (i) B. pergamonensis; (j) C. graecus; (k) C. hellenicus; (1) C. stephanidisi; (m) Eudontomyzon sp. Almopaios; (n) H. huso; (o) K. goerneri; (p) K. milleri; (q) O. theophilii; (r) P. epiroticus; (s) P. laconicus; (t) P. hellenicus; (u) S. economidisi; (v) S. graecus; (w) Squalius. sp. Evia; (x) V. letourneuxi; (y) V. robertae.

\section{Results}

In total, 800 records were utilized from 169 lakes and 631 lotic sites from 51 river basins. By using solely lotic data from field surveys, our results indicated low NIFS richness $\left(0-1.40\right.$ NIFS per $\left.1 \mathrm{~km}^{2}\right)$ throughout the country, with the exception of specific hotspots in central and northern Greece (Figure 3a). On the contrary, by utilizing bibliographic data from lentic ecosystems the patterns of predictive NIFS richness was predominately high (2.7-4.3 NIFS per $\left.1 \mathrm{~km}^{2}\right)$ in most areas of the country, followed by moderate NIFS predicted richness (1.5-2.6 NIFS per $1 \mathrm{~km}^{2}$ ) in the remaining parts (Figure $3 \mathrm{~b}$ ). 


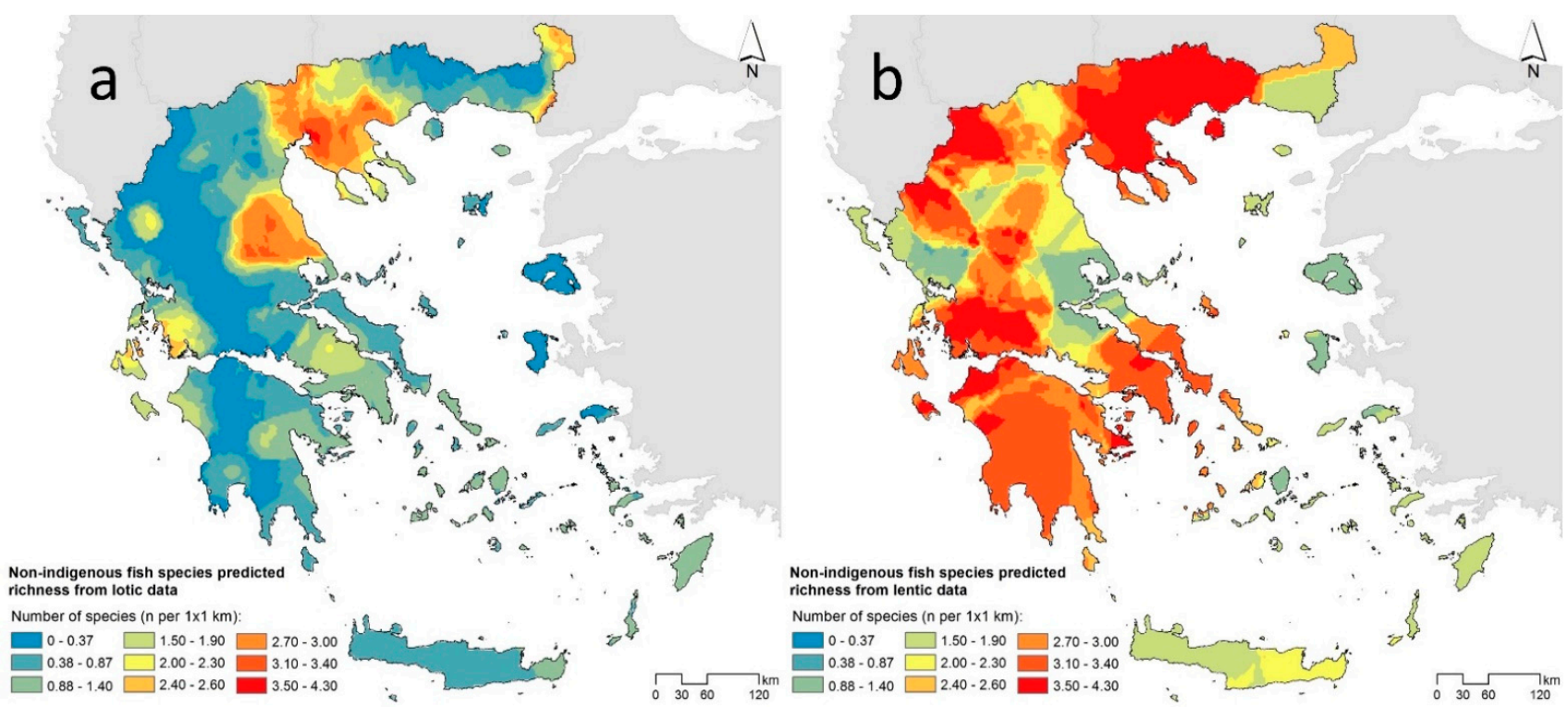

Figure 3. Patterns of the predicted richness of non-indigenous fish species derived from (a) lotic data and (b) lentic data.

Overall, we recorded 52 NIFS in 154 lentic and 51 lotic ecosystems (265 sites) of which 17 were categorized as alien and 35 as translocated. The five most widespread NIFS within Greece included four aliens, namely Gambusia holbrooki occurring in 223 locations (53.1\%), Carassius gibelio occurring in 187 locations (44.52\%), Lepomis gibbosus occurring in 113 locations (26.9\%), Pseudorasbora parva occurring in 93 locations (22.14\%), and one translocated species Cyprinus carpio occurring in 109 locations (25.95\%). NIFS richness ranged from single species (176 sites) up to 12 fish species (one site-Lake Pamvotis). Our results indicate that freshwater ecosystems under high NIFS richness are located mainly in lowland areas of western, central, and northern Greece (Figure 3a), usually near large cities and the presence of lentic ecosystems with well-developed commercial and recreational fisheries. On the contrary, areas with low NIFS richness were observed in mountainous regions and within small river basin areas in southern Greece and the Aegean islands (Figure 4a).
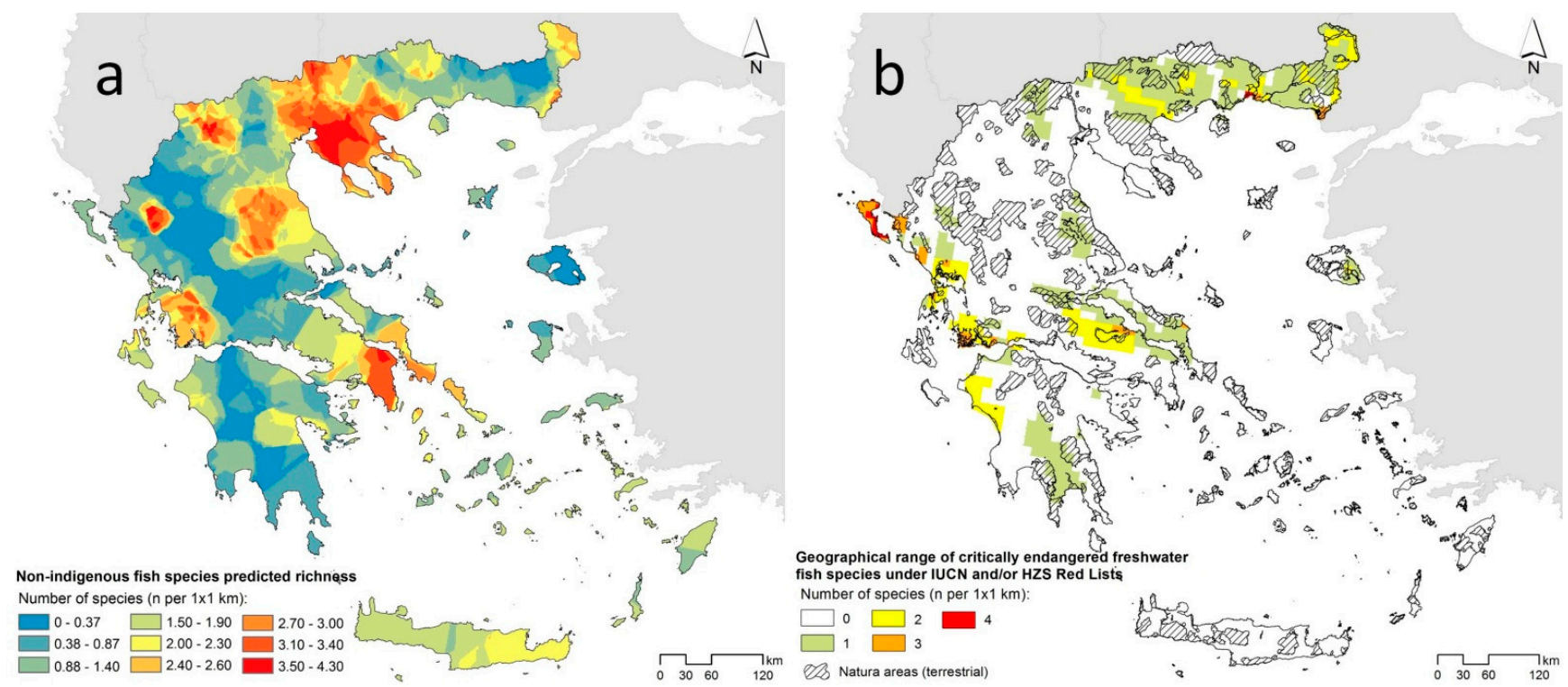

Figure 4. (a) Patterns of predicted richness of non-indigenous fish species (indicating high invasion pressure) and (b) geographical distribution range of critically endangered freshwater fish species and protected areas (Natura 2000 network). 
The distribution of the $\mathrm{CR}$ freshwater fish species in Greece was scattered throughout the aquatic ecosystems of the country (Figure 2), covering approximately $28 \%\left(36,708 \mathrm{~km}^{2}\right)$ of the entire area of Greece (Table 2). In most areas, only one CR fish species occurs or is known to have occurred (69.9\%); however, in some ecosystems two or more species co-occur (Figure 4b; Table 2). The highest species richness of CR fish species was observed in the north and northeastern, western, and central parts of Greece, while no CR fish species were recorded in the mountainous areas of northern and central Greece, in the majority of the Aegean or Ionian Islands, or the island of Crete (Figure 4b).

Table 2. Distributional coverage of critically endangered (CR) freshwater fish species in Greece.

\begin{tabular}{ccc}
\hline CR Category (n of Species) & Area $\left.\mathbf{( k m}^{\mathbf{2}}\right)$ & Percent $\mathbf{( \% )}$ \\
\hline 1 & 25,658 & 69.9 \\
2 & 8925 & 24.3 \\
3 & 1796 & 4.9 \\
4 & 329 & 0.9 \\
\hline Total & $\mathbf{3 6 , 7 0 8}$ & $\mathbf{1 0 0}$
\end{tabular}

Overlapping areas of CR species with moderate to high NIFS richness (1.5-4.3 NIFS per $\left.1 \mathrm{~km}^{2}\right)$ were relatively high $(\sim 50 \%)$ (Table 3$)$. These areas were located in the western, central-east, and northern part of Greece (Figure 4). Shared absences indicating both low CR species and NIFS and thus low overlapping areas were observed in the mountainous regions of central Greece, the Aegean Islands, and the Island of Crete (Table 3; Figure 5). The above is to be expected since most Aegean Islands (with the exception of the Island of Lesbos) as well as the Island of Crete lack any CR species.

Table 3. The proposed class boundaries (low, moderate, high) of the overlapping areas of nonindigenous and critically endangered freshwater fish species, the actual areas, and the total percentage for each category.

\begin{tabular}{|c|c|c|c|c|c|c|}
\hline & Category & & $\begin{array}{c}\text { Area } \\
\left(\mathrm{km}^{2}\right)\end{array}$ & $\begin{array}{l}\text { Percent } \\
(\%)\end{array}$ & $\begin{array}{c}\text { Total Area } \\
\left(\mathrm{km}^{2}\right)\end{array}$ & $\begin{array}{c}\text { Total Percent } \\
(\%)\end{array}$ \\
\hline \multirow{3}{*}{ Low } & & $0-0.37$ & 4270 & 11.6 & \multirow{3}{*}{18.408} & \multirow{3}{*}{50.1} \\
\hline & & $0.38-0.87$ & 5906 & 16.1 & & \\
\hline & & $0.88-1.40$ & 8232 & 22.4 & & \\
\hline \multirow{3}{*}{ Moderate } & & $1.50-1.90$ & 7154 & 19.5 & \multirow{3}{*}{14.997} & \multirow{3}{*}{40.9} \\
\hline & & $2.00-2.30$ & 3926 & 10.7 & & \\
\hline & & $2.40-2.60$ & 3917 & 10.7 & & \\
\hline \multirow{4}{*}{ High } & & $2.70-3.00$ & 1637 & 4.5 & \multirow{3}{*}{3.303} & \multirow{3}{*}{9.0} \\
\hline & & $3.10-3.40$ & 1371 & 3.7 & & \\
\hline & & $3.50-4.30$ & 295 & 0.8 & & \\
\hline & Total & & 36,708 & 100 & & \\
\hline
\end{tabular}

Only, five CR species were recorded exclusively in areas with low NIFS richness (Barbus pergamonensis, Knipowitschia goerneri, Knipowitschia milleri, Oxynoemacheilus theophilii and Pungitius hellenicus). The CR fish species co-occurring in areas with moderate to high NIFS richness were: Pelasgus epiroticus (Lake Pamvotis), Valencia robartae, Salaria economidisi (Acheloos basin), Scardinius graecus (Lakes Yliki and Paralimni), Cobitis stephanidisi (Lake Karla basin), Alburnus macedonicus (Lake Doirani), Barbus euboicus, Squalius sp. Evia (streams of Euboea Island) and Caspiomyzon hellenicus (Strymon basin) (Figure 5; Table 4). 


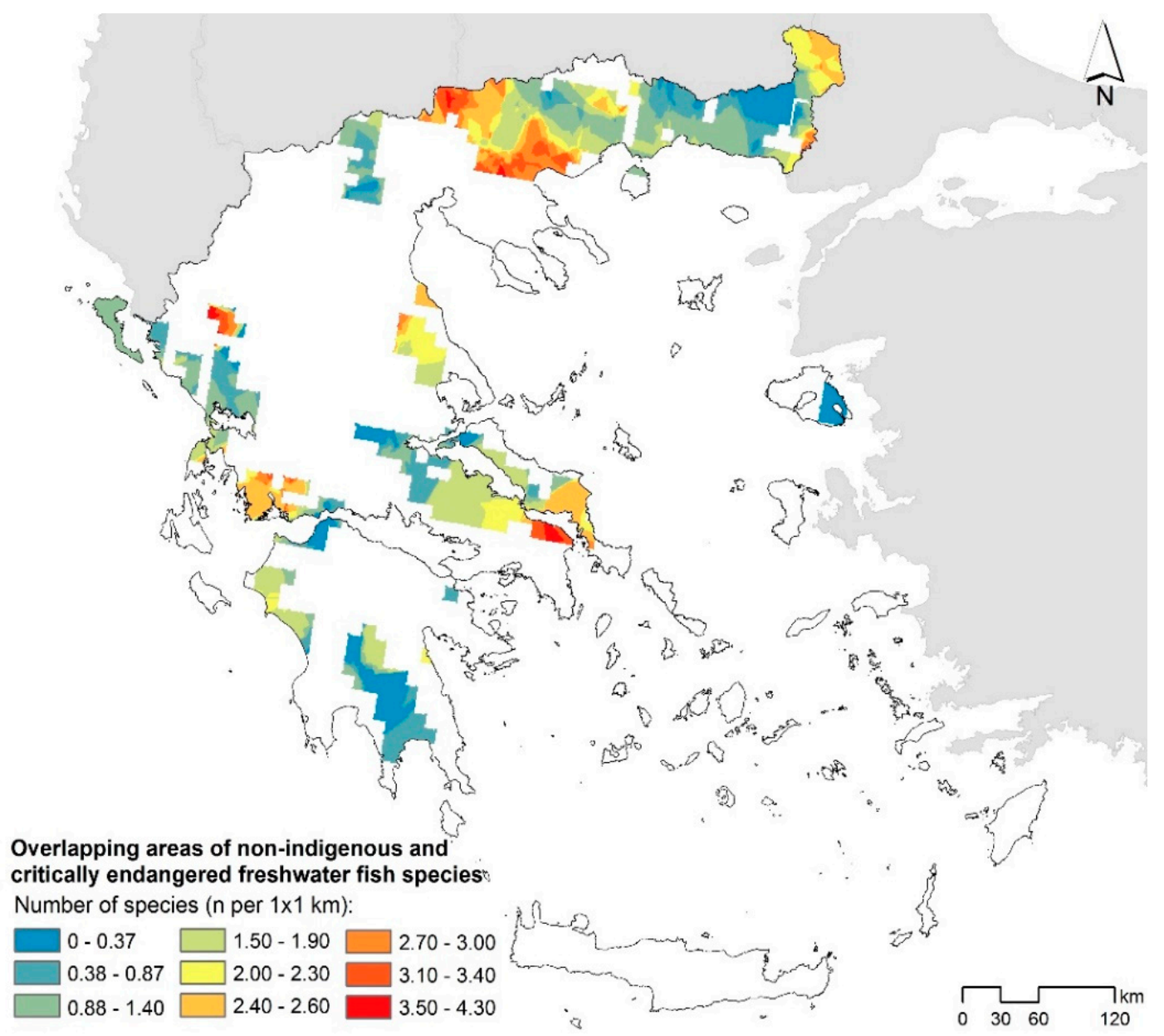

Figure 5. Overlapping areas between the distributions of NIFS and critically endangered freshwater fish species.

A quarter of the overlapping areas (24.8\%) fall well within the NATURA 2000 network (Figure 6a), where management bodies could implement control or mitigation programs to minimize the negative impacts from NIFS to native biodiversity. However, the majority of the distribution areas of CR fish species in Greece are located outside of protected areas (75.2\%; Figure 6a) and any additional anthropogenic stressors have the potential to increase pressure to the populations of these species. Moreover, the vast majority of the overlapped areas within the protected zones encompassed only one or two CR fish species per $1 \mathrm{~km}^{2}: 78.4 \%$ and $17.2 \%$, respectively (Figure $6 \mathrm{~b}$ ), while three or four CR fish species per $1 \mathrm{~km}^{2}$ covered considerably smaller areas (4.4\% in total; Figure $\left.6 \mathrm{~b}\right)$. In addition, the area coverage of moderate to high NIFS richness was similar within the unprotected $(49.3 \%)$ and protected areas $(44.5 \%)$ (Figure $6 c, d)$, potentially indicating that no effective preventive measures are applied to prevent NIFS spread in protected areas. 
Table 4. The distributional coverage and the overlapping areas per critically endangered freshwater fish species for each NIFS predicted richness category (low, moderate, high).

\begin{tabular}{lcccc}
\hline \multicolumn{1}{c}{ Species } & $\begin{array}{c}\text { Area } \\
\left(\mathbf{k m}^{\mathbf{2}}\right)\end{array}$ & $\begin{array}{c}\text { Low } \\
(\mathbf{0}-\mathbf{1 . 4 0 )}\end{array}$ & $\begin{array}{c}\text { Area per Category (\%) } \\
\text { Moderate } \\
\mathbf{( 1 . 5 - 2 . 6 0 )}\end{array}$ & $\begin{array}{c}\text { High } \\
(\mathbf{2 . 7}-\mathbf{4 . 3 )}\end{array}$ \\
\hline Acipenser naccarii & 1026 & 85.96 & 14.04 & - \\
Acipenser stellatus & 11,614 & 31.90 & 48.90 & 19.20 \\
Acipenser sturio & 7369 & 29.00 & 58.30 & 12.70 \\
Alburnus macedonicus & 277 & - & 53.43 & 46.57 \\
Alburnus vistonicus & 4187 & 97.04 & 2.96 & - \\
Alosa vistonica & 433 & 94.46 & 5.54 & - \\
Aphanius almiriensis & 153 & 63.40 & 36.60 & - \\
Barbus euboicus & 562 & 20.28 & 65.30 & 14.41 \\
Barbus pergamonensis & 461 & 100 & - & - \\
Caspiomyzon graecus & 602 & 96.51 & 3.32 & 0.17 \\
Caspiomyzon hellenicus & 499 & 60.32 & 39.68 & - \\
Cobitis stephanidisi & 1296 & - & 94.21 & 5.79 \\
Eudontomyzon sp. Almopaios & 1473 & 91.99 & 8.01 & - \\
Huso huso & 292 & 20.21 & 79.79 & - \\
Knipowitschia goerneri & 301 & 100 & - & - \\
Knipowitschia milleri & 403 & 100 & - & - \\
Oxynoemacheilus theophilii & 100 & 100 & - & - \\
Pelasgus epiroticus & 400 & 9.50 & 18.50 & 72.00 \\
Pelasgus laconicus & 3120 & 87.66 & 12.34 & - \\
Pungitius hellenicus & 737 & 100 & - & - \\
Salaria economidisi & 202 & - & 83.17 & 16.83 \\
Scardinius graecus & 2343 & 30.99 & 69.01 & - \\
Squalius sp. Evia & 53 & - & 100 & - \\
Valencia letourneuxi & 2152 & 90.20 & 9.80 & - \\
Valencia robertae & 2428 & 28.54 & 66.85 & 4.61 \\
\hline & & & & - \\
\hline
\end{tabular}

a

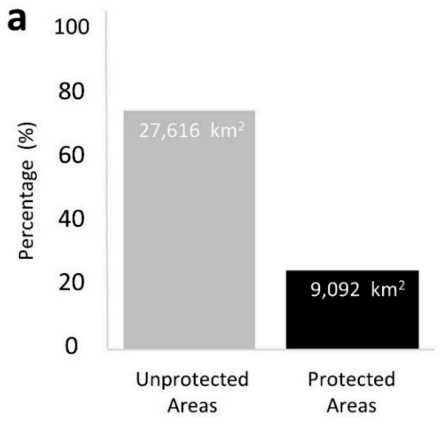

C NIFS in unprotected areas

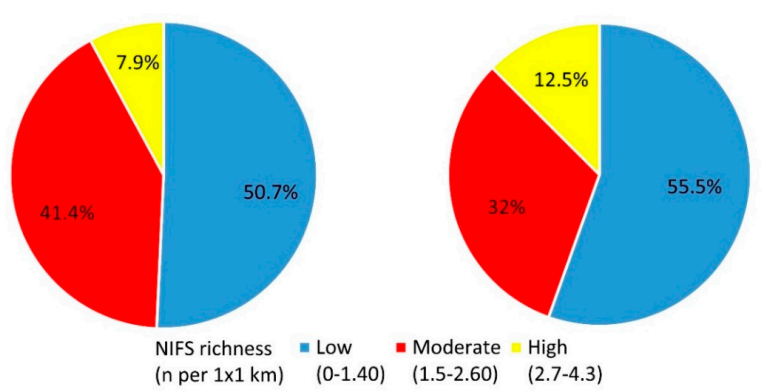

b Within Natura areas

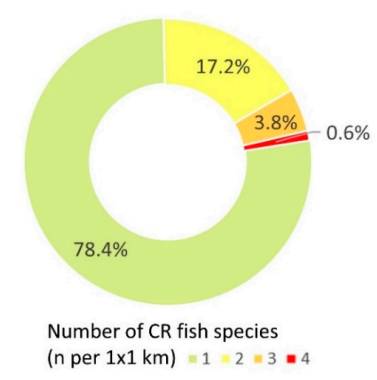

d NIFS within Natura areas

Figure 6. (a) The overlapping areas of NIFS and CR freshwater fish species in unprotected areas (grey) and protected areas (black); (b) the area coverage (\%) of CR freshwater fish species richness within the protected areas; (c) the area coverage (\%) of NIFS richness in unprotected areas; and (d) within protected areas. 


\section{Discussion}

Until fairly recently, Greece was a country that had relatively few alien fish species compared to other European states [23]. However, nowadays, whole riverine fish assemblages are rapidly changing as non-indigenous fish species spread into several lotic and lentic ecosystems [24]. This study aimed to identify the potential overlapping areas of NIFS against fish species that are under the highest extinction threat category (CR) in Greece. The findings of this study demonstrate that many freshwater ecosystems in the country are under significant invasion pressure and concurrently exhibit high biodiversity conservation value; this problem is now pressing throughout the European Mediterranean basins $[25,26]$.

Predictive patterns of NIFS richness varied largely by utilizing different data sources (i.e., bibliographic data for lentic and field surveys for lotic). These immense differences in NIFS predicted richness between lotic and lentic ecosystems can be attributed to several factors. For instance, bibliographic data usually overestimate the total species richness of an ecosystem, since species that were once reported could now have been extirpated. This is actually true for aliens in several Greek lentic systems, which were once stocked with fishes that were unable to develop viable populations (i.e., Acipenser baeri, Acipenser gueldenstaedtii, Ctenopharyngodon idella, Hypophthalmichthys nobilis, Oncorhynchus kisutch, Oncorhynchus mykiss) [17]. Thus, these species will be included in checklists and eventually in future analyses despite the fact that they could be currently extirpated. In this study, our combined analysis is indicative of the situation at the country-wide level, as far as possible, in all inland freshwater ecosystems. Correspondingly, results of how bibliographical data may depict overestimated NIFS richness in Greece were reported by a recent study [22], indicating that alien fish species were relatively restricted in Greek rivers, based on sampling data in contrast with bibliographic data.

Similar to other recent studies, the most common NIFS within the overlapping areas were Greece's four most widespread and abundant aliens G. holbrooki, C. gibelio, L. gibbosus, and P. parva as well as the translocated C. carpio, Salmo farioides, and Economidichthys pygmaeus [14,22]. Evidently, the most recorded NIFS display limnophylic (lacustrine) life history strategies. Indeed, apart from the introductions of cold-water species such as salmonids which are primarily conducted in the upper catchments of rivers and streams, most species introductions in Greece concern warm-water lacustrine species in lowland rivers and lentic ecosystems [27]. In most sites, NIFS richness comprised single species; however, in a single case NIFS richness raised up to 12 fish species (Lake Pamvotis), indicating high invasive pressure. Historically, Lake Pamvotis included only four native species; however, during the 1930s until the late 1990s several NIFS were introduced for purposes of eutrophication control or fisheries enhancement [24]. Overall, lowland riverine areas and lentic ecosystems with well-developed commercial and recreational fisheries indicated higher NIFS richness in comparison with small streams in higher altitudes or in arid regions (e.g., southern Greece and the Aegean islands).

According to the latest Red List assessment at the European level, more than 37\% of the freshwater fish species are considered as threatened; $15 \%$ as Vulnerable, $10 \%$ as Endangered, and $12 \%$ as CR status [11]. The IUCN analysis shows that Greece hosts the most species under a threatened status and the most critically endangered freshwater fish species in Europe [28]. Despite this fact, few conservation actions have been applied to protect the CR freshwater fish species of Greece, while how NIFS affect their viability is almost totally neglected. According to current distributional records, two CR species (P. epiroticus and C. stephanidisi) co-occurring in areas with moderate to high NIFS richness are considered on the brink of extinction [17], while an additional species (Alosa vistonica) which indicated low to moderate overlapping areas with the distributions of NIFS has recently been assessed as extinct [29].

Despite the fact that our analysis utilizes broad-scale data of NIFS and CR fish species inhabiting both lentic and lotic ecosystems, we acknowledge its limitations by not incorporating the connectivity of aquatic ecosystems into the approach [30,31]. Generally, 
geostatistical techniques are suitable for modeling features that are inherently continuous [32], which contrasts with the fragmentation observed in freshwater ecosystems and the geographic isolation of the islands. However, in an attempt to mitigate the latter issues we used an extensive sampling/site network, thus narrowing the number of maximum neighbors and minimizing the distance points used to perform the interpolation. Furthermore, we acknowledge that some formerly widespread species, with marginal distributions in the country, are now probably totally extirpated as wild native populations from Greece. For instance, regions which include wild populations of sturgeons (Huso huso, Acipenser sturio, Acipener naccarri, Acipenser stellatus) [17] may have an overestimated distributional coverage bias of $\mathrm{CR}$ fish species.

Even though there has been a rapid growth in developing protected areas worldwide [33], such efforts are not usually optimally designed for freshwater biodiversity. Many conservationists accept that freshwater conservation must relate to a separate ecological realm, beyond the terrestrial or marine, whose specific recognition may have important consequences for both biodiversity conservation and the wider water management issues [34]. A recent study that aimed to overlap the ranges of threatened species, based on the IUCN Red List and Natura 2000 delineations in Greece [35], reported that species belonging to the class of Actinopterygii (including exclusively freshwater species) were covered fairly well within protected areas. However, the aforementioned study also included freshwater fish species within the threatened categories of Endangered and Vulnerable, thus this increase in spatial overlap with protected areas of the Natura 2000 sites is expected, since more species occupy wider areas. In our study, by focusing on the highest extinction threat category (CR), we revealed that the largest part of the distributional ranges of $\mathrm{CR}$ freshwater fish species fall outside protected areas. Finally, it is evident, based on the absence of relevant scientific literature, that conservation actions targeting $C R$ freshwater fish species in Greece have rarely been applied. In fact, out of the 25 CR freshwater fish species, concrete conservation actions have been applied only for four species mainly by conducting conservation translocations (A. naccarii, [36]; Pungitius hellenicus, [37], V. letourneuxi, and V. robertae; [38]).

IUCN and national red listing assessment schemes are scheduling to modify a number of listed species categories as new reviews of vulnerability status are revised (i.e., some species that are Critical may be downgraded to Endangered and so forth). Although the new red listing revisions may alter the status of some species, in our opinion, most of the species utilized in our study should remain as important guiding species for conservation planning. The Hellenic Zoological Society's Greek Red List procedure was last reviewed in 2009, lagging far behind many other EU states; efforts to revise it have recently been initiated through funding scheduled from the Hellenic Ministry of Environment and Energy. Recently, a new review of Mediterranean freshwater fish species has also begun by IUCN experts and is expected to be completed in 2021. In the current work, we solely utilized the highest extinction threat level category as a proxy indicator for identifying areas of outstanding conservation interest in a rapid screening process that may be easily repeated and transferable to other states and for future monitoring.

Conservation planning in its entirety is a highly complex process encompassing several steps in order to develop and implement the protection, conservation, and enhancement of natural resources. As freshwater protected area effectiveness is usually challenging [39], especially regarding NIFS threats [40], the need for well-designed protected areas and management plans for freshwater biodiversity is a necessity for critically endangered fishes and the ecosystems that host them in Greece. Unraveling the spatial overlap between NIFS and critically endangered fish species can support the first stages of targeted conservation planning and contribute to preliminary actions to minimize the potential negative effects. Future studies should aim to a) identify and assess broader important fish areas for conservation and $b$ ) assess how the combined effects of various stressors (i.e., NIFS, water abstraction, pollution, river fragmentation, etc.) can affect the populations of the threatened freshwater fish species of Greece under a climate change 
context. Moreover, there is a need for high-quality comprehensive reviews regarding the ichthyofaunal compositions of Greek lentic ecosystems, which will exclude all species with questionable occurrences and clarify the actual and current status of NIFS introductions. Finally, future work should also address the analysis of species traits of the mixed fish assemblages (native and NIFS) to better understand the functional organization of these novel ecosystems.

Author Contributions: Conceptualization, N.K., L.V., and S.Z.; methodology, N.K., L.V., and S.Z.; formal analysis, N.K. and L.V.; investigation and data curation, N.K., S.Z., and L.V.; writing-original draft preparation, N.K., S.Z., and L.V.; writing-review and editing, N.K., S.Z., L.V., and O.-I.K.; visualization, N.K. and L.V.; supervision, O.-I.K. and S.Z.; project administration, O.-I.K., N.K., and S.Z. All authors have read and agreed to the published version of the manuscript.

Funding: This research is co-financed by Greece and the European Union (European Social FundESF) through the Operational Programme «Human Resources Development, Education and Lifelong Learning 2014-2020» in the context of the project "Interdisciplinary assessment of non-indigenous fish fauna in the freshwater ecosystems of Greece" (MIS 5047785).

Institutional Review Board Statement: Not applicable.

Data Availability Statement: Not applicable.

Conflicts of Interest: The authors declare no conflict of interest. The founding sponsors had no role in the design of the study; in the collection, analyses, or interpretation of data; in the writing of the manuscript; and in the decision to publish the results.

\section{References}

1. Ceballos, G.; Ehrlich, P.R.; Barnosky, A.D.; García, A.; Pringle, R.M.; Palmer, T.M. Accelerated modern human-induced species losses: Entering the sixth mass extinction. Sci. Adv. 2015, 1, e1400253. [CrossRef] [PubMed]

2. Johnson, C.N.; Balmford, A.; Brook, B.W.; Buettel, J.C.; Galetti, M.; Guangchun, L.; Wilmshurst, J.M. Biodiversity losses and conservation responses in the Anthropocene. Science 2017, 356, 270-275. [CrossRef]

3. Turvey, S.T.; Crees, J.J. Extinction in the Anthropocene. Curr. Biol. 2019, 29, R982-R986. [CrossRef]

4. Duncan, J.R.; Lockwood, J.L. Extinction in a field of bullets: A search for causes in the decline of the world's freshwater fishes. Biol. Conserv. 2001, 102, 97-105. [CrossRef]

5. Darwall, W.; Smith, K.; Allen, D.; Seddon, M.; Mc Gregor Reid, G.; Clausnitzer, V.; Kalkman, V. Freshwater biodiversity-A hidden resource under threat. In The 2008 Review of the IUCN Red List of Threatened Species; Vié, J.C., Hilton-Taylor, C., Stuart, S.N., Eds.; IUCN: Gland, Switzerland, 2009; pp. 43-53.

6. Schinegger, R.; Palt, M.; Segurado, P.; Schmutz, S. Untangling the effects of multiple human stressors and their impacts on fish assemblages in European running waters. Sci. Total Environ. 2016, 573, 1079-1088. [CrossRef]

7. Jarić, I.; Heger, T.; Monzon, F.C.; Jeschke, J.M.; Kowarik, I.; McConkey, K.R.; Pyšek, P.; Sagouis, A.; Essl, F. Crypticity in biological invasions. Trends Ecol. Evol. 2019, 34, 291-302. [CrossRef] [PubMed]

8. Deinet, S.; Scott-Gatty, K.; Rotton, H.; Twardek, W.M.; Marconi, V.; McRae, L.; Baumgartner, L.J.; Brink, K.; Claussen, J.E.; Cooke, S.J.; et al. The Living Planet Index (LPI) for Migratory Freshwater Fish; Technical Report; World Fish Migration Foundation: Groningen, The Netherlands, 2020.

9. Piria, M.; Copp, G.H.; Dick, J.T.; Duplić, A.; Groom, Q.; Jelić, D.; Caffrey, J.M. Tackling invasive alien species in Europe II: Threats and opportunities until 2020. Manag. Biol. Invasions 2017, 8, 273-286. [CrossRef]

10. Darwall, W.; Carrizo, S.; Numa, C.; Barrios, V.; Freyhof, J.; Smith, K. Freshwater Key Biodiversity Areas in the Mediterranean Basin Hotspot: Informing Species Conservation and Development Planning in Freshwater Ecosystems; IUCN: Cambridge, UK, 2014.

11. Freyhof, J.; Brooks, E. European Red List of Freshwater Fishes; Publications Office of the European Union: Luxembourg, 2011.

12. Economou, A.N.; Giakoumi, S.; Vardakas, L.; Barbieri, R.; Stoumboudi, M.T.; Zogaris, S. The freshwater ichthyofauna of Greece-an update based on a hydrographic basin survey. Mediterr. Mar. Sci. 2007, 8, 91-166. [CrossRef]

13. Economidis, P.S.; Banarescu, P.M. The distribution and origins of freshwater fishes in the Balkan Peninsula, especially in Greece. Int. Rev. Ges. Hydrobiol. Hydrogr. 1991, 76, 257-284. [CrossRef]

14. Koutsikos, N.; Vardakas, L.; Vavalidis, T.; Kalogianni, E.; Dimitriou, E.; Kalantzi, O.I.; Zogaris, S. Defining non-indigenous fish assemblage types in Mediterranean rivers: Network analysis and management implications. J. Environ. Manag. 2021, 278, 111551. [CrossRef]

15. Moyle, P. Novel aquatic ecosystems: The new reality for streams in California and other Mediterranean climate regions river research and applications. River Res. Appl. 2013, 30, 1335-1344. [CrossRef]

16. Buoro, M.; Olden, J.D.; Cucherousset, J. Global Salmonidae introductions reveal stronger ecological effects of changing intraspecific compared to interspecific diversity. Ecol. Lett. 2016, 19, 1363-1371. [CrossRef] [PubMed] 
17. Barbieri, R.; Zogaris, S.; Kalogianni, E.; Stoumboudi, M.T.; Chatzinikolaou, Y.; Giakoumi, S.; Kapakos, Y.; Kommatas, D.; Koutsikos, N.; Tachos, V.; et al. Freshwater Fishes and Lampreys of Greece: An Annotated Checklist. Monographs on Marine Sciences No. 8; HCMR: Athens, Greece, 2015.

18. Chatzinikolaou, Y.; Zogaris, S.; Leonardos, I.; Bobori, D.; Koutrakis, E.; Tachos, V.; Anagnopoulos, N.; Loukatos, A.; Konstantinidis, E.; Bourdaniotis, N.; et al. Geographical mapping in GIS of potential distribution of each species and documented technical report. In The Framework of the Project "Monitoring and Evaluation of Conservation Status of EU's Interest Icthyofanuna Species in Greece"; GMEECC, Joint Venture Anagnopoulos Nikolaos-EPEM S.A.-Konstantinidis Ilias: Athens, Greece, 2014. (In Greek)

19. Zogaris, S.; Tachos, V.; Economou, A.N.; Chatzinikolaou, Y.; Koutsikos, N.; Schmutz, S. A model-based fish bioassessment index for Eastern Mediterranean rivers: Application in a biogeographically diverse area. Sci. Total Environ. 2018, 622, 676-689. [CrossRef] [PubMed]

20. Schmutz, S.; Cowx, I.G.; Haidvogl, G.; Pont, D. Fish-based methods for assessing European running waters: A synthesis. Fish. Manag. Ecol. 2007, 14, 369-380. [CrossRef]

21. Economou, A.N.; Zogaris, S.; Vardakas, L.; Koutsikos, N.; Chatzinikolaou, Y.; Kommatas, D.; Tachos, V. Developing policy-relevant river fish monitoring in Greece: Insights from a nation-wide survey. Mediterr. Mar. Sci. 2016, 17, 302-322. [CrossRef]

22. Koutsikos, N.; Zogaris, S.; Vardakas, L.; Kalantzi, O.I.; Dimitriou, E.; Economou, A.N. Tracking non-indigenous fishes in lotic ecosystems: Invasive patterns at different spatial scales in Greece. Sci. Total Environ. 2019, 659, 384-400. [CrossRef] [PubMed]

23. Bianco, P.G. Potential role of the palaeohistory of the Mediterranean and Paratethys basins on the early dispersal of EuroMediterranean freshwater fishes. Ichthyol. Explor. Freshw. 1990, 1, 167-184.

24. Leonardos, I.D.; Kagalou, I.; Tsoumani, M.; Economidis, P.S. Fish fauna in a Protected Greek lake: Biodiversity, introduced fish species over a 80-year period and their impacts on the ecosystem. Ecol. Freshw. Fish. 2008, 17, 165-173. [CrossRef]

25. Sommerwerk, N.; Wolter, C.; Freyhof, J.; Tockner, K. Components and drivers of change in European freshwater fish faunas. J. Biogeogr. 2017, 44, 1781-1790. [CrossRef]

26. Grapci-Kotori, L.; Vavalidis, T.; Zogaris, D.; Šanda, R.; Vukić, J.; Geci, D.; Ibrahimi, H.; Bilalli, A.; Zogaris, S. Fish distribution patterns in the White Drin (Drini i Bardhë) river, Kosovo. Knowl. Manag. Aquat. Ecosyst. 2020, 421, 29. [CrossRef]

27. Piria, M.; Simonović, P.; Kalogianni, E.; Vardakas, L.; Koutsikos, N.; Zanella, D.; Joy, M.K. Alien freshwater fish species in the Balkans-Vectors and pathways of introduction. Fish. Fish. 2018, 19, 138-169. [CrossRef]

28. International Union for Conservation of Nature's Red List of Threatened Species. Available online: https://www.iucnredlist.org/ (accessed on 17 January 2021).

29. Bobori, D. Research and Proposals for the Protection of Near-Extinct Endemic Species of the Ichthyofaunal in Lakes Vistonis and Mitrikou (Alosa vistonica \& Alburnus vistonicus); Management Body of Delta Nestos-Vistonis-Ismarida: Thessaliniki, Greece, 2015; Unpublished Report. (In Greek)

30. Moilanen, A.; Leathwick, J.; Elith, J. A method for spatial freshwater conservation prioritization. Freshw. Biol. 2008, 53, 577-592. [CrossRef]

31. Beger, M.; Grantham, H.; Pressey, R.L. Conservation planning for connectivity across marine, freshwater, and terrestrial realms. Biol. Conserv. 2010, 143, 565-575. [CrossRef]

32. Hengl, T.; Sierdsema, H.; Radović, A.; Dilo, A. Spatial prediction of species' distributions from occurrence-only records: Combining point pattern analysis, ENFA and regression-kriging. Ecol. Modell. 2009, 220, 3499-3511. [CrossRef]

33. Pimm, S.L.; Jenkins, C.N.; Abell, R.; Brooks, T.M.; Gittleman, J.L.; Joppa, L.N.; Sexton, J.O. The biodiversity of species and their rates of extinction, distribution, and protection. Science 2014, 344, 6187. [CrossRef] [PubMed]

34. van Rees, C.B.; Waylen, K.A.; Schmidt-Kloiber, A.; Thackeray, S.J.; Kalinkat, G.; Martens, K.; Domisch, S.; Lillebø, A.I.; Hermoso, V.; Grossart, H.-P.; et al. Safeguarding freshwater life beyond 2020: Recommendations for the new global biodiversity framework from the European experience. Conserv. Lett. 2020, 14, e12771. [CrossRef]

35. Spiliopoulou, K.; Dimitrakopoulos, P.G.; Brooks, T.M.; Kelaidi, G.; Paragamian, K.; Kati, V.; Oikonomou, A.; Vavylis, D.; Trigas, P.; Lymberakis, P.; et al. The Natura 2000 network and the ranges of threatened species in Greece. Biodivers. Conserv. 2021, 30, 1-17. [CrossRef]

36. Paschos, I.; Nathanailides, C.; Kagalou, I.; Leka, E.; Tsoumani, M.; Perdikaris, C. The prospects for restoring the nearly extinct population of the Adriatic sturgeon Acipenser naccarii Bonaparte 1836 (Acipenseridae) in Greece. Aqua. J. Ichthyol. Aquat. Biol. 2003, 7, 123-132.

37. Zogaris, S.; Skoulikidis, N.; Dimitriou, E. River and wetland restoration in Greece: Lessons from biodiversity conservation ini-tiatives. In The Rivers of Greece; Skoulikidis, N.T., Dimitriou, E., Karaouzas, I., Eds.; Springer: Berlin/Heidelberg, Germany, 2017.

38. Kalogianni, E.; Koutsikos, N.; Vardakas, L.; Giakoumi, S.; Chatzinikolaou, Y.; Oikonomou, A. Impacts of the alien mosquitofish on the abundance and condition of two Mediterranean native fish. Med. Mar. Sci. 2019, 20, 727-735. [CrossRef]

39. Acreman, M.; Hughes, K.A.; Arthington, A.H.; Tickner, D.; Dueñas, M.A. Protected areas and freshwater biodiversity: A novel systematic review distils eight lessons for effective conservation. Conserv. Lett. 2020, 13, e12684. [CrossRef]

40. Ruchin, A.B.; Osipov, V.V.; Fayzulin, A.I.; Bakin, O.V.; Tselishcheva, L.G.; Bayanov, N.G. Chinese sleeper (Perccottus glenii Dybowski, 1877)(Pisces, Odontobutidae) in the reserves and National Parks of the middle and lower Volga (Russia): Mini-review. Aquac. Aquar. Conserv. Legis. 2019, 12, 1114-1124. 